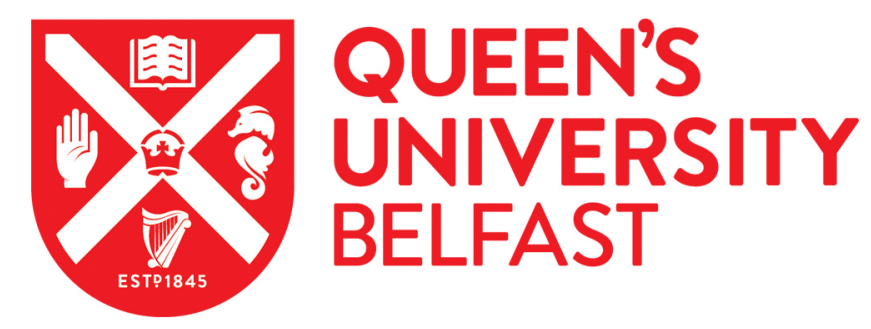

\title{
The German Federal Constitutional Court's Ruling on Outright Monetary Transactions (OMT) - Another Step Towards National Closure?
}

Schiek, D. (2014). The German Federal Constitutional Court's Ruling on Outright Monetary Transactions (OMT) - Another Step Towards National Closure? German Law Journal, 15(2), 329-342.

http://www.germanlawjournal.com/volume-15-no-02/

Published in:

German Law Journal

Document Version:

Publisher's PDF, also known as Version of record

Queen's University Belfast - Research Portal:

Link to publication record in Queen's University Belfast Research Portal

Publisher rights

(c) 2014 The German Law Journal, Inc

\section{General rights}

Copyright for the publications made accessible via the Queen's University Belfast Research Portal is retained by the author(s) and / or other copyright owners and it is a condition of accessing these publications that users recognise and abide by the legal requirements associated with these rights.

Take down policy

The Research Portal is Queen's institutional repository that provides access to Queen's research output. Every effort has been made to ensure that content in the Research Portal does not infringe any person's rights, or applicable UK laws. If you discover content in the Research Portal that you believe breaches copyright or violates any law, please contact openaccess@qub.ac.uk. 


\title{
Special Issue
}

The OMT Decision of the German Federal Constitutional Court

\section{The German Federal Constitutional Court's Ruling on Outright Monetary Transactions (OMT) - Another Step towards National Closure?}

\author{
By Dagmar Schiek ${ }^{*}$
}

\section{A. Introduction}

The German Federal Constitutional Court (FCC) ruling of 14 January $2014^{1}$ deserves a thorough evaluation on several accounts: It is the first ever reference by the FCC to the Court of Justice of the European Union (CJEU), it represents a continuation of FCC case law aimed at restricting the impact of European Union law as interpreted by the Court of Justices of the European Union (CJEU) on German law as well as questioning Germany's participation in an ever closer European Union, and it has the potential to dictate the future course of the EU's Economic and Monetary Union (EMU).

This case note discusses three aspects of this decision. First, it considers the aims of challenging the youngest measures to contain the euro currency crisis before the FCC, focusing on the question in how far the claims are based on national closure as opposed to an ever closer union of the peoples of Europe. Secondly it analyzes in how far the aims the claims pursue are reflected in the FCC's response. Thirdly, it considers the substantive relevance of this reference, highlighting the surprisingly vague consequences the FCC envisages should the CJEU not re-interpret the OMT decision as the FCC suggests, and illuminating the strategic aims of the reference without deference. In conclusion, it sketches the remaining scope for the EU to engage in or at least facilitate transnational solidarity.

\section{B. The Context of the Claim}

The ruling continues a line of FCC case law which resulted from the fact that from 1993, when the Treaty of Maastricht introduced the common currency, each step towards

\footnotetext{
*University of Leeds. Email: d.g.schiek@leeds.ac.uk.

${ }^{1}$ Bundesverfassungsgericht [BVerfG - Federal Constitutional Court], Case No. 2 BvR 2728/13 et al, (Jan. 14, 2014), http://www.bverfg.de/entscheidungen/rs20140114_2bvr272813en.html. All references to the ruling and the dissenting opinion use the paragraph numbers established in this internet publication by the FCC.
} 
further EU integration has been challenged before this court. Well after the well-known Maastricht ruling, ${ }^{2}$ a group of plaintiffs had already claimed that Germany's entrance into Economic and Monetary Union without a political union would be unconstitutionalwithout success. ${ }^{3}$ A similarly constituted group also challenged the financial support for Greece in 2010, ${ }^{4}$ and the Constitutional Treaty. ${ }^{5}$ While in 1998, those challenging the participation of Germany in the second stage of EMU were isolated in their arguments, the Treaty of Lisbon was challenged by several claimants. ${ }^{6}$ The decision of 14 Januarypublished on 7 February 2014-derived from seven challenges against the Germany's participation in the European Stability Mechanism (ESM) and the Treaty on Stability, Consolidation and Governance (TSCG), also referred to as Fiscal Compact, which partly also challenge European Union legislation nicknamed the "six-pack."” The FCC has delivered its decision on these claims on 18 March $2014 .{ }^{8}$ As expected, the FCC rejected the claims, following its ruling on applications for interim relief of 12 September $2012 .{ }^{9}$

The 14 January 2014 decision to refer questions to the CJEU only affects a partition of those seven claims. These proceedings are still pending before the FCC. On 6 September 2012, the ECB's Governing Council proclaimed conditions for making Outright Monetary Transactions (OMT) in secondary markets of sovereign bonds in the euro area concerning euro area states receiving support negotiated with the ECB and the EU Commission. One condition was that the Memoranda of Understanding established for receiving support

2 Bundesverfassungsgericht [BVerfG - Federal Constitutional Court], Case No. 2 BvR 2134/92, 2 BvR 2159/92, 1993 ENTSCHEIDUNGEN DES BUNDESVERFASSUNGSGERICHTS [BVERFGE] 89, 155 (Oct. 12, 1993).

${ }^{3}$ Bundesverfassungsgericht [BVerfG - Federal Constitutional Court], Case No. 2 BvR 1877/97, 2 BvR 50/98, 1998 ENTSCHEIDUNGEN DES BUNDESVERFASSUNGSGERICHTS [BVERFGE] 97, 350 (Mar. 31, 1998) (rejecting the complaint).

${ }^{4}$ Bundesverfassungsgericht [BVerfG - Federal Constitutional Court], Case No. 2 BvR 987/10, 2 BvR 1485/10, 2 BvR 1099/10, 2011 ENTSCHEIDUNGEN DES BUNDESVERFASSUNGSGERICHTS [BVERFGE] 129, 124 (Sept. 7, 2011) (“Greek bailout", rejecting complaint).

${ }^{5}$ Bundesverfassungsgericht [BVerfG - Federal Constitutional Court], Case No. 2 BvE 1/05 - 2 BvR 636/05, 2005 ENTSCHEIDUNGEN DES BUNDESVERFASSUNGSGERICHTS [BVERFGE] 112, 363 (Apr. 28, 2004) (rejecting as inadmissible).

${ }^{6}$ Bundesverfassungsgericht [BVerfG - Federal Constitutional Court], Case No. 2 BvE 2/08 et. al., 2009 ENTSCHEIDUNGEN DES BUNDESVERFASSUNGSGERICHTS [BVERFGE] 123, 267 (June 30, 2009).

\footnotetext{
${ }^{7}$ Regulations 1173/2011 (on effective enforcement of budgetary surveillance in the Euro-Area), 1174/2011 (on enforcement measures to correct macroeconomic imbalances), 1175/2011 (amendment of the Stability and Growth pact of 1997 preventive arm), 1176/2011 (on prevention and correction of macroeconomic imbalances); 1177/2011 (amendment of SGP-corrective arm) and Directive 2011/85 (on requirements for budgetary frameworks of member states).

8 Bundesverfassungsgericht [BVerfG - Federal Constitutional Court], Case No. 2 BvR 1390/12 et al, (Mar. 18, 2014), https://www.bundesverfassungsgericht.de/entscheidungen/rs20140318_2bvr139012en.html.

${ }^{9}$ Bundesverfassungsgericht [BVerfG - Federal Constitutional Court], Case No. 2 BvR 1390/12 et al, 2012 ENTSCHEIDUNGEN DES BUNDESVERFASSUNGSGERICHTS [BVERFGE] 132, 139 (Sept. 12, 2012).
} 
would be complied with, and the other that the OMT was necessary to re-establish rational interest rates for government yields. ${ }^{10}$ The mere announcement of OMT's proved remarkably efficient: Interest rates for Spanish and Irish government debt service declined considerably only on grounds of the announcement. ${ }^{11}$ However, in Germany, OMT's were perceived as quasi-loans at the expense of domestic tax payers. ${ }^{12}$ Accordingly, five out of seven claimants expanded their challenges to encompass the German government's and the Bundestag's (German Federal Parliament) reaction to and participation in those OMTs. The FCC separated these additions from the original claims, ${ }^{13}$ and thus enabled itself to refer the questions to the CJEU.

\section{The Substance and Purposes of the Claims Raised}

This section will consider the content of and the purposes for the five claims, which were not summarized by the FCC. ${ }^{14}$ Most of the claimants made available their submissions online, indicating that they consider these claims as part of a political campaign on Germany's correct actions concerning the euro-area crisis.

\section{The Claimants and their Applications}

Mr. Gauweiler, a former Member of Parliament for the $\mathrm{CSU}^{15}$, represented by Professor Murswiek and RA Bub, ${ }^{16}$ has a long record of challenging Germany's involvement with the European Union. In challenging the ESM, TSCG and the OMT decision, ${ }^{17}$ Gauweiler alleges that the EU institutions act beyond their competences (ultra vires, see for a summary the FCC's ruling on the Lisbon Treaty ${ }^{18}$ ) and also challenges the unlimited risk for Germany's budget. He stresses that Germany is not represented in the ECB Council in proportion to its

\footnotetext{
${ }^{10}$ ECB press release of Sept. 6, 2012, quoted in the case discussed here under paragraph 3. The ECB's own justification of the program can be found in ECB Monthly Bulletin October 2012, page 7-9 (box 1). The TARGET2 system, which is also challenged by some of the applicants before the FCC, will not be considered in this note.

${ }^{11}$ Zolt Darvas, The ECB's Magic Wand, 47 INTERECONOMICs 266-67 (2012).

${ }^{12}$ On the irrationality of that perception, see Paul De Grauwe \& Yuemei Ji, The fiscal implications of the ECB's bond-buying programme, voxEU, 2013, http://bit/ly/14M6SUd.

${ }^{13}$ Procedural decision of Dec. 17, 2013 (allocating new case numbers to these applications).

${ }^{14}$ This is also mentioned as problematic in the dissenting opinion by Judge Lübbe-Wolff. BVerfG, Case No. 2 BvR $2728 / 13$ at para. 2 of dissent.

${ }^{15}$ Christlich-Soziale Union, the Bavarian arm of the German conservative party.

${ }^{16}$ New case number: 2 BvR 2727/13.

${ }^{17}$ Submission of 11.10 .2012 , on file with the author.

${ }^{18}$ See BVerfG, Case No. 2 BvE 2/08.
} 
economic contribution, but rather only has one vote, just as Greece or Cyprus. This, in his view, is a violation of the principle of democracy under the German constitution. He applied for a ruling that the Federal Government is obliged to bring an action against the ECB Governing Council Decision on Outright Monetary Transactions, as well as taking any action that contributes to rescinding this decision, or inhibiting its implementation.

The group of professors represented by K.A. Schachtschneider, Professor emeritus at University of Erlangen, ${ }^{19}$ already raised a constitutional challenge against Germany's participation in the EU's Economic and Monetary Union, ${ }^{20}$ as well as its ratification of the Lisbon Treaty, ${ }^{21}$ and of course also against the first "bail-out" that saved Greece from insolvency in 2010. ${ }^{22}$ Their counsel, Schachtschneider, also represented Martin Brunner in his challenge of the Maastricht Treaty in 1992, and has recently authored a legal opinion commissioned by the Austrian FPÖ ${ }^{23}$ outlining how Austria should leave the EU. This group, while consistent in its opposition to Germany's participation in the EMU as constituted by the Treaties, is diverse in its composition: Two members of the Social Democratic Party ${ }^{24}$ are joined by the top candidate of "Alternative für Deutschland" ${ }^{25}$ and a publisher. ${ }^{26}$ Their principled argument concerning EMU is that Germany's participation is too risky as long as the participating economies are not sufficiently converged and monetary union is not supported by economic union. As in their challenge of the first "bail-out" of Greece, they also relied on the German constitution's social state principle, which in their view underpins the individual constitutional guarantee of property rights of citizens. Regarding the OMT decision, the group's application ${ }^{27}$ challenges that OMT's subject the German federal budget to uncontainable risks, thus undermining the budgetary autonomy of the

\footnotetext{
${ }^{19}$ New case number: 2 BvR 2729/13.

${ }^{20}$ See BVerfG, Case No. 2 BvR 2134/92, 2 BvR 2159/92.

${ }^{21}$ See BVerfG, Case No. 2 BvE 2/08.

${ }^{22}$ See BVerfG, 2 BvR 1877/97, 2 BvR 50/98.

${ }^{23}$ Freiheitspartei Österreich (Austrian Freedom Party), a right-wing populist party founded by Jörg Haider in the 1990s.

${ }^{24}$ Wilhelm Hankel \& Wilhelm Nölting.

25 Joachim Starbatty. "Alternative für Deutschland" was founded much later than the activities of the group against EMU began. As its name-alternative perspectives for Germany-indicates, the group challenges the frequent reliance on "TINA" (there is no alternative) in debates around the European Union and in particular the euro area crisis. Its aims include that Germany leaves the EU or at least the euro-area, which is supported by populist arguments stressing different national characters in the EU, among other arguments. The party did not gain a sufficient number of votes for representation in the Bundestag so far.

${ }^{26}$ Bruno Bandulet. Bandulet has been considered as associated with the dissolved "Bund Freier Bürger," a former grouping which also aimed at standing for parliamentary elections.

${ }^{27}$ Submission of Nov. 13, 2012, on file with the author.
} 
German parliament through funding foreign states. They also question the conditionality of OMTs as infringing democratic self-governance of affected states. Further, monetary financing by the ECB is seen as not only contradicting Article 125 TFEU, but also as changing the EU into a European Federal State, which again requires a change of the German constitution and a plebiscite. The application is primarily to hold the OMT decision as unconstitutional and thus ineffective. An auxiliary application is made for an obligation of the Federal Government to challenge the OMT decision before the CJEU.

The largest group of claimants is organized by "Mehr Demokratie" (more democracy), a civil society organization represented by the former minister of Justice, Herta DäublerGmelin, Christoph Degenhard, Professor at Leipzig University, and Bernhard Kempen, Professor at University of Cologne. ${ }^{28}$ "Mehr Demokratie" was founded in 1988, to lobby for a plebiscite on a new German constitution after re-unification. It has focused on promoting elements of direct democracy in Germany and its states as well as ensuring democratic principles in elections. As regards the EU, the NGO was involved in lobbying for the citizens' initiative. As far as the containment of the euro crisis is concerned, "Mehr Demokratie" states on its web page ${ }^{29}$ that they pursue a further reform of the EU Treaties through the ordinary Treaty revision procedure under Article 48 TEU. This method comes closest to their ideals because it requires establishing a convention in which national parliaments and civil society are represented. They also claim that they support further EU integration, but in a more democratic form than hitherto. They constitute the latest addition to the euro-challenge, and their constitutional complaint is the largest mass-claim before the Federal Constitutional Court in its history. ${ }^{30}$ Their claim ${ }^{31}$ in particular focuses on preventing the communization of debt, the resulting risks for the German budget, and ultimately the democratic representation of their clients as well as protecting the rule of law within the EU from being undermined by emergency measures with unpredictable consequences. Thus, the challenges can be interpreted as criticizing the fact that the crisis containment measures did not, in their entirety, take place within the supranational framework of the EU, but rather use intergovernmental instruments such as international Treaties. The applications concerning OMT do not contain any obligation of the federal government to raise a claim before the CJEU. They seek an obligation of the federal government to work towards repealing the OMT decision, an obligation to ensure that liability of Germany resulting from making OMT's is limited and an obligation of the German federal parliament to ensure that it has full control about any payment in support for ailing euro area countries, in order to safeguard its budgetary autonomy.

\footnotetext{
${ }^{28}$ New case number: 2 BvR 2730/13.

${ }^{29} \mathrm{http} / / /$ www.mehr-demokratie.de/.

${ }^{30}$ Originally, these were two claims, raised by about 11000 and 26000 citizens respectively.

${ }^{31}$ Submissions of Nov. 14, 2012 \& July 8, 2013, on file with the author.
} 
A further group of claimants is represented by the advocate Professor Dr. Markus C. Kerber $^{32}$, whose europolis web page states that his seventeen clients are mainly businesspeople, including for example Olaf Henkel $^{33}$ and some owners of small and medium sized businesses. In contrast to the other claims, which are available on the internet in great detail, the information on the web page is restricted to press announcements outlining the general litigation strategy. The information implies that the claimants are interested in re-invigorating the EU's credibility by leading it back to the principles of ordo-liberalism in order to overcome interventionist politics. ${ }^{34}$ The applicant aimed, among others, at a reference to the CJEU. Together with Beatrix von Storch, ${ }^{35}$ he also raised a claim to annul the ECB Governing Council's OMT decision and ECB guidelines 2012/641 and 2012/18 concerning specific conditions thereof before the CJEU's General Court. This claim was rejected as inadmissible. ${ }^{36}$ Following a call for supporters via the web-page of "Zivile Koalition," ${ }^{37}$ this claim was raised by more than 5000 citizens. As regards the OMTs, the application is for a challenge of the legality of the decision, which can only be achieved by a reference to the CJEU.

Further, one of the remaining opposition parties in parliament, "DIE LINKE"38 is part of the procedures, represented by Andreas Fisahn, Professor at Bielefeld University, and Hans Peter Schneider, Professor of University of Hannover. ${ }^{39}$ They have raised a cumulative constitutional complaint in the name of a number of party members as well as an

\footnotetext{
${ }^{32}$ New case number 2 BvR 2731/13. RA Professor Dr. Markus C Kerber also represented claimants in the challenge of the Lisbon Treaty, See supra note 18) and the "Greek bailout," See supra note 4. He should not be confused with Markus Kerber, acting director of BDI (Bund Deutscher Industrie) from July 2011, http://www.bdi.eu/bdi_english/649_660.htm, Feb. 20, 2014.

${ }^{33}$ Olaf Henkel, who was the former president of the BDI, now also supports AfD, as stated in the last chapter of his most recent book: OlAF HENKEL, DIE EURO-LÜGNER: UNSINNIGE RETTUNGSPAKETE, VERTUSCHTE RISIKEN-SO WERDEN WIR GETÄUSCHT (Munich: Heyne, 2013).

${ }^{34}$ The background of the claims is explained in a number of press releases, available at http://www.europolisonline.org/.

${ }^{35}$ Beatrix von Storch also supports AfD, and was one of their candidates for the German general elections in Berlin, as is still reported on her web page, http://www.beatrixvonstorch.de/, Feb. 23, 2014.

${ }^{36}$ General Court decision in case T-492/12 of Dec. 10, 2013, nyr (available in French and German).

37 Zivile Koalition has its registered office in Berlin, at the same address as B von Storch. Available at: http://www.zivilekoalition.de/aktionen/schluss-mit-der-schuldenunion-raus-aus-dem-esm-zurueck-zurdemokratie.

${ }^{38}$ This party results from a merger of the PDS (Partei des Demokratischen Sozialismus - Party of Democratic Socialism), a successor of the SED (Sozialistische Einheitspartei Deutschlands, the governing party of the GDR) and some Western German parties, among others a split off from the Social Democrats, after German reunification, www.die-linke.de.

${ }^{39}$ New case number 2 BvE 13/13.
} 
application on behalf of the LINKE faction in the federal parliament ("Organstreitverfahren"). ${ }^{40}$ As regards the OMT proceedings, only the application in the "Organstreitverfahren" is pending. This application is mainly based on a violation of democracy. However, counsel for DIE LINKE also criticize the content of the measures containing the Eurocrisis, and in particular take up an argument that DIE LINKE has already promoted in their challenge to the Treaty of Lisbon: The lack of engagement with social justice, and thus a violation not only of the social state principle within the Federal Republic of Germany, but also against the EU's own normative commitment to a social market economy and social justice. The argument thus goes beyond the territory of Germany by highlighting the social consequences of the conditionality of any support for other Member States. However, as in the challenge of the Treaty of Lisbon, there is also the tendency to claim any social state policy for the German constituent power, thus promoting national closure in social policy, whose EU level equivalent can at maximum consist in coordination of national policies. This contradictory state of affairs is related to a change in position of DIE LINKE towards a more EU friendly stance. As regards the OMT, DIE LINKE apply for the Bundestag to be under an obligation to pursue that the OMT decision is revised and only to give its consent to any individual acquisition of bonds after having obtained comprehensive information.

\section{The FCC as Campaign Ground, and the Substantive Reasons}

It seems particularly worthwhile to note that the FCC is utilized not only as a forum to substantively discuss the adequacy of actions of the government and even of debates in parliament, but also as a space to demonstrate the wide support for such arguments in the population. This is most obvious in the "Mehr Demokratie" claim, brought by more than 10,000 citizens. However, the claim led by Kerber before the CJEU also attempts to demonstrate that high numbers of claimants can be mobilized. While German procedural law does not allow for mass litigation formally, the public campaign for gaining a high number of supporters suggests that those representing the claimants wish to suggest that the FCC is the only remaining stronghold for democracy.

The substantive arguments brought against the OMT decision specifically are of course partly constrained by past FCC rulings, which again were framed by the arguments developed in earlier proceedings, as discussed below. However, within that frame, the claimants and the applicant also challenge politics substantively. These substantive submissions show some remarkable differences and commonalities.

\footnotetext{
${ }^{40}$ This procedure is one of two constitutional procedures before the FCC, and allows a party or faction in the parliament to clarify questions of political party law, electoral or parliamentary law. See BundesverfassungsGerICHTSGESETZ [BVerfGG] [Federal Constitutional Court Act], Aug. 29, 2013, BGBI I. at 3463, § 93.
} 
The Schachtschneider group and DIE LINKE concur in highlighting the negative effects of conditionality under the ESM "bailouts" for social policy and the social state principle. Reference to the social state principle had also been made by Mr. Gauweiler in his challenge of the "Greek bailout," ${ }^{41}$ though in relation to the risks for purchasing power of citizens in Germany. In these proceedings, Gauweiler does not refer to the social states principle in challenging the OMT decision, though his counsel does mention the social component of Article $23 \mathrm{GG}$. However, the claimants represented by Schachtschneider rely on the social state principle in challenging the conditionality of the envisaged OMT decisions, again referring to a loss of purchasing power for German citizens through exposure of the German budget to risks emanating from other euro area states. ${ }^{42}$ The LINKE application refers to social state principles twice. On the one hand, it states that any expansion of the EU's competence concerning social security and collective bargaining through Memorandums of Understanding must not be approved by the German parliament. ${ }^{43}$ On the other hand, they claim that the conditionality of any support through the ESM, as well as through OMT has negative consequences for the welfare state in receiving countries, which they state contravenes Article 23 Grundgesetz and Article 3 paragraph 3 TEU. $^{44}$

All the claimants rely on the argument that the lack of limitation for the use of OMTs constitutes an incalculable risk for the federal budget. They argue that this endangers the identity of the German constitution, because the parliament's competence to decide upon the federal budget will be undermined. This is, in their view, a consequence of the fact that the EU violates the prohibition of monetary financing established in Article 125 (2) TFEU. Further, the Schachtschneider group and Mr Gauweiler submit that Article 88 GG only allows a currency union based on stability and an independent ECB. That independence, in their view, presupposes that the ECB does not engage in economic policy. These claimants thus endorse the orientation of EMU on the principles of budget and monetary stability in their endeavor to defend the independence of the German citizens from distortions in the euro area.

Ultimately, while some of the submissions refer to the consequences of the EU policy for other Member States, the applications aim to isolate internal German policy from the unwanted impact of EU policy. This is independent from the political spectrum from which a certain claim emerges. Those claiming that EMU must remain strictly within the

\footnotetext{
${ }^{41}$ The FCC confirmed that the social state principle is part of the "constitutional identity" of Germany, but did not consider it to encompass stability of the currency. See BVerfG, Case No. 2 BvE 2/08.

${ }^{42}$ Submissions of Nov. 2012, on file with the author, 31.

${ }^{43}$ Submissions of May 26, 2013, on file with the author, 2.

${ }^{44}$ Id. at 2, 7. See also the reference to their argumentation in the Lisbon ruling. BVerfG, Case No. 2 BvE 2/08 at para. 117.
} 
constraints of budget and monetary stability demand national closure in the form of budget independence. Those criticizing the European Union and its EMU for their negative impact on national social policy increasingly also strive for national closure of national social policy instead of a more efficient EU level social policy. This is not only characteristic for politics, but also for academia. For example, in a recent contribution Florian Rödl advises that trade unions should no longer hope for a more social EU, but rather defend a purely national scope of, for example, wage bargaining. ${ }^{45}$

\section{The FCC's Response}

As is well known, the main response of the FCC was to refer the matter to the CJEU.

\section{The Reference to the CJEU is a Far Shot from Deference}

Reports in the media and the reactions of "the markets" suggest that the FCC has deferred to the CJEU with its reference. ${ }^{46}$ This, however, is a misconception. The FCC used most of its judgment to expand on why the OMT decision is an ultra vires act, thus assuming the competence to interpret EU law [56-94]. The reason is that this decision is seen as economic policy, which can be separated from monetary policy, and that it exposes the German budget to risks emanating from the participation of Germany in the Eurozone. In a very short paragraph the FCC then proposes that the OMT decision is interpreted restrictively. In particular the decision must be rewritten as to exclude any "debt cut" as well as any unlimited selective purchases of government bonds, to avoid any influence on prices for government bonds. ${ }^{47}$ The FCC reserves the right to decide whether the OMT decision is compatible with EU law. ${ }^{48}$

The reference thus constitutes a threat that OMT decision will be unconstitutional in Germany if the CJEU does not interpret it restrictively in such a way that it no longer fulfils the intended purpose.

\footnotetext{
${ }^{45}$ Florian Roedl, Autoritär und unso, MitBeStIMmUng MAGAZIN, 2012, http://www.boeckler.de/40891_40906.htm. Challenges to this argument are explored more expansively in Dagmar Schiek, The EU Constitution of Social Governance in an Economic Crisis: in Defence of a Transnational Dimension to Social Europe, 20 MAASTRICHT J. OF COMP. \& EUR. L., 185-208 (2013).

${ }^{46}$ For example, Paul Taylor states for Reuters that the FCC side-steps the question who decides about sovereignty in the EU - http://www.reuters.com/article/2014/02/07/us-germany-court-ecb-precedent-analysisidUSBREA161/420140207 (last visited Feb. 23, 2014).

${ }^{47}$ BVerfG, Case No. 2 BvR 2728/13 at para. 99-100 (the main purpose of the decision was to influence markets).

${ }^{48}$ Id. at para. 101.
} 


\section{The Factual Relevance of any Unconstitutionality of the OMT Decision}

Considering the severity of this threat, one would have expected that any ultra vires character of the OMT decision would also have very severe consequences within Germany.

However, it is far from clear what consequences exactly the FCC envisages. While it states that non institution of Germany may implement the OMT decision, ${ }^{49}$ it remains vague what this means as long as the ECB does not need to act on its announcement to make OMTs. Even if it acts on this announcement, it is highly questionable whether the German central bank will have any impact on this. In contrast to the SMT procedure, the OMT procedure does not necessarily presuppose cooperation of the national central banks in the framework of the ECBS. In that case, the specific obligations emanating from the ruling remain opaque. The German government is obliged to ensure that the integration program is observed, and that the EU acts in conformity with the German constitution. This may also be achieved by changing the constitution. ${ }^{50}$ The Bundestag is obliged to consider any non-constitutional transfer of sovereign rights. ${ }^{51}$ However, neither citizens nor a faction in the Bundestag can claim that parliament achieves a specific result as a consequence of those deliberations. ${ }^{52}$ Justice Lübbe-Wolff characterizes such obligations as "inconsequential communicative behavior," ${ }^{53}$ and, as Justice Gerhard, holds the applications inadmissible for the reason that the FCC should not decide on inconsequential issues.

\section{What is the Substantive Relevance in Terms of Integration?}

However, the FCC ruling could also be interpreted as giving the German institutions the power of obstructing EU policy upon any finding of its FCC that EU policy is ultra vires.

This idea rests on the Lisbon ruling, ${ }^{54}$ which established the concept of an inalienable set of sovereign powers that cannot be abandoned by any EU legislation or change to the EU Treaties in a way congruent with Germany's constitution. This again derives from a specific approach to democracy as well as to socio-economic policy as part of sovereignty.

\footnotetext{
${ }^{49}$ Id. at para. 45 .

${ }^{50}$ Id. at para. 48.

${ }^{51}$ Id. at para. 53.

${ }^{52}$ Id. at para. 51-52, 54.

${ }^{53}$ Id. at para. 20 (dissenting opinion).

${ }^{54}$ See supra note 18.
} 
The FCC conceded in the Lisbon ruling that "(d)emocratic constitutional states can only gain a formative influence on an increasingly mobile society, which is increasingly linked across borders, through sensible cooperation which takes account of their own interest as well as of their common interest." ${ }^{\prime 55}$ While this constitutes the basis for Germany's openness to European integration, the FCC also insisted that any genuinely EU level politics in those fields which define statehood must not compete with the competences of the German state. Among others, this is linked to the doctrine that democratic representation can only be established at national level, and not through the European Parliament or any emanations of direct democracy at EU level. ${ }^{56}$ This has been characterized as "constitutional nationalism," perceives of democratic legitimacy through a demos characterized by ethnic homogeneity. ${ }^{58}$ The principle of national closure is thus built into the case law of the FCC, arguably originating from the problematic Maastricht decision, ${ }^{59}$ and specified in the principle of inalienable constitutional powers in the Lisbon ruling. The Lisbon ruling goes far beyond the Maastricht ruling: in principle it enables any citizen to claim a violation of the individual right to vote if an EU act violates any constitutional principle of the German Grundgesetz (German Constitution - GG) which the FCC has characterized as inalienable constitutional powers.

The claims leading to the OMT ruling relied on two elements of the inalienable constitutional powers established in the Lisbon ruling: The fundamental fiscal decisions on public revenue and public expenditure and decisions on the shaping of circumstances of life in a social state. ${ }^{60}$ The reference to the social state principle had already been made in Brunner's application against the Maastricht Treaty, ${ }^{61}$ while the "fiscal sovereignty" had first been acknowledged in the Lisbon-ruling. ${ }^{62}$ In the January 2014 ruling, the FCC stopped short from acknowledging a violation of the right to vote (Article $38 \mathrm{GG}$ ) through the endangering of the social state principle through devaluation of the currency or through

\footnotetext{
${ }^{55}$ BVerfG, Case No. 2 BvR 2728/13 at para. 221.

${ }^{56}$ Id. at para. 280-292.

${ }^{57}$ Sylvie Goulard, Frankfurter Allgemeine Zeitung (Apr. 1, 2010).

${ }^{58}$ Armin Steinbach, The Lisbon Judgment of the German Constitutional Court-New Guidance on the Limits of European Integration?, 11 GERMAN L. J. 367, 389 (2010).

59 Joseph Weiler, Does Europe Need a Constitution? Demos, Telos and the German Maastricht Decision, 1 EURO. L. J. 219-58 (1995).

${ }^{60}$ See BVerfG, Case No. 2 BvE 2/08 et. al. at para. 178 et. seq., 181 et. seq.

${ }^{61}$ See BVerfG, Case No. 2 BvR 2134/92, 2 BvR 2159/92 at para. 168-169.

${ }^{62}$ See BVerfG, Case No. 2 BvE 2/08.
} 
conditionality. It only relied on the overall budgetary responsibility of the German Bundestag. ${ }^{63}$

However, the FCC derived the potential violation of Article $38 \mathrm{GG}$ from the ultra vires character of the OMT decision. This led to a substantive evaluation of that decision under the standards of EU law, as the FCC reads it. In this context, the FCC refers to the conditionality and its impact on national social policy in Member States whose governments are potentially profiting from OMT (paragraph 75). This ultimately rests on the principle established in the Lisbon ruling that the main substance of realizing the social state principle must remain the sole competence of Germany. This limitation again rests on a similar principle of national closure as the limitation of true democracy to the territory of Member States.

The national closure relied upon by some of the claimants remains decisive for the FCC's verdict of the ultra vires character of the OMT decision. The tentative steps in some of the submissions of the LINKE towards invoking the EU's value of social justice have not become relevant for the substance of the ruling. Under the doctrines of the FCC, the EU must mainly remain a passive on-looker in socio-economic policies while the Member States take center stage. This, according to the FCC, also requires the EU to exercise restraint in its monetary policy, and to refrain from correcting market distortions.

\section{E. Conclusion-Is There Any Way Forward?}

This result is questionable under two perspectives.

On the one hand, as Justice Lübbe-Wolff stresses in her dissenting opinion, the FCC assumes an indirect competence to scrutinize EU policies. It thus claims for itself to decide central pillars of the EU's governance of the euro area. Even if such a decision would not be taken by a national court, but rather by a national parliament, this would be problematic in that the consequences of this national decision would impact far beyond the nation state. As Lübbe-Wolf puts it

The question is, ... whether the national perspective... is still the appropriate and the constitutional one where a decision may have legal and factual consequences of the magnitude and reach at issue here. That some few independent German judges-invoking the German interpretation of the principle of democracy, the limits of admissible competences of the ECB following from this

${ }^{63}$ Id. at para. 28 seq. 
interpretation, and our reading of Art. 123 et seq. TFEU-make a decision with incalculable consequences for the operating currency of the euro zone and the national economies depending on it appears as an anomaly of questionable democratic character. (dissenting opinion Lübbe-Wolff, paragraph 28)

She thus demands to refrain from judicialization of economic policy, in an attempt to reverse the juridification of Economic and Monetary Union. In essence this is based on juxtaposing the political and the legal field of European integration: The European Union should be allowed to construct economic and monetary policies at least in an emergency without being under the constant control of the German Constitutional Court. If accepted, this might re-open the field for political argument.

Substantively, the question remains whether there is any scope for EMU to develop beyond the constraints of budget and monetary stability, which is utilized to justify strictly supply side oriented socio-economic policies to be imposed on all Member States. In order to overcome that restraint, a teleological interpretation of provisions such as Article 125 TFEU in conjunctions with other provisions of the same Treaty chapter has been proposed. $^{64}$ For future critical analysis of European Economic and Monetary Union, one should consider an even wider perspective. It is an historical irony that the European Union has explicitly committed for the first time to social justice, combating poverty, striving for social inclusion and the promotion of solidarity between the Member States and within societies (Articles 2, 3 TEU and Article 9 TFEU) at just the same time when it had to face the impact of the global financial crisis within the euro area. In developing its responses to this challenge, the EU closely followed the specific design of the euro area through the Treaty of Maastricht, which imposes overly strict obligations to achieve so-called financial stability of public budgets if followed literally. The teleological, and indeed systematic interpretation of the EU Treaties would require to interpret the provisions in the chapter on EMU in line with the fundamental values of the EU. This would allow a dynamic development of the EU Treaty base to embrace such economic and monetary policies that can do justice to the EU's commitments to social inclusion and solidarity between Member States.

The question remains whether these commitments permit maintaining national closure in social policy. They may well require EU level social policy initiatives and real solidarity between Member States. ${ }^{65}$ If the latter is true, we still need to establish whether and how

\footnotetext{
${ }^{64}$ Paul Craig, Pringle: Legal Reasoning, Text, Purpose and Teleology, 20 MAASTRICHT J. OF COMP. \& EUR. L. 3, 7-9 (2013).

65 Dagmar Schiek, The EU Constitution of Social Governance in an Economic Crisis: in Defence of a Transnational Dimension to Social Europe, 20 MAASTRICHT J. OF COMP. \& EUR. L. 185-208 (2013). See also Economic and Social Integration: The Challenge for EU Constitutional Law (Cheltenham: Edward Elgar, 2012), 308.
} 
the legal framework for EMU can be interpreted in a way that does not prevent developing adequate policies for this. If such interpretation can be developed, it may well contradict the FCC's demands for EU social and economic policy to remain at the level of mere coordination. The recent decision of 18 March 2014, which cannot be analyzed in full here, does not seem to confirm the restrictive line of argument established in Lisbon ruling and the OMT reference commented here, but rather allows scope for government and parliament to engage in European integration. It might thus be a reason to hope for more judicial restraint in relation to EU socio-economic politics, which again might allow for Germany to participate in a social Europe with stronger common legal commitments to social justice. 